\title{
The Impact of Information and Communication Technology (ICT) Development on Economic Growth in Sudan: An Application of ARDL Bounds Testing Approach
}

\author{
Ahmed Mohammed Khater Arabi \\ College of Business Administration, \\ Taibah University, kingdom of Saudi Arabia \\ Babiker Abdelrazig Wagee Allah \\ College of Business Administration, \\ Taibah University, kingdom of Saudi Arabia
}

\begin{abstract}
The aim of this study to investigates the impact of Information and Communication Technology (ICT) development on economic growth in Sudan. Annually data over the period (1980-2014) of economic growth (GDP), Information and Communication Technology ICT (Fixed phone line, mobile cellular and internet subscribers per 100 inhabitants) and macroeconomic factor (Gross fixed capital formation and labor force) were modeled. Using the bound testing approach to co integration and Error Correction Model (ECM), developed within an Autoregressive Distributed Lag (ARDL) framework, the study investigates whether a long-run relationship exists among the variables. From the results, it is evident that there is an existence of a long run relationship between ICT and economic growth. The short run dynamic model also reveals that the speed of convergence to equilibrium is moderate implying that there is a short run relationship between ICT and economic growth.
\end{abstract}

Keywords: economic growth, ARDL, ICT

\section{INTRODUCTION}

Explaining the sources of economic growth has ranked amongst the most significant issues that economists have examined. Romer's 1986 work began a set of theoretical and empirical analyses focusing on the endogeneity of the growth process as compared to Solow (1956) type neoclassical growth models which use an aggregate production function approach and exogenous technical changes. Information and Communication Technology (ICT) has become, within a very short time, one of the basic building blocks of modern society. Many countries now regard understanding ICT and mastering the basic skills and concepts of ICT as part of the core of economic growth process. Within the past decade, the new ICT tools have fundamentally produced significant transformations in industry, agriculture, medicine, business, engineering and other production fields; moreover ICT has an added value to the final goods and services. The widespread diffusion of the Internet, mobile telephony and broadband networks all demonstrate how pervasive this technology has become. But how precisely does ICT affect economic growth? And what are the conditions under which ICT can become effectively enhance the economic performance?

Telecommunications infrastructure investment can lead to economic growth in several ways. Most obviously, investing in telecommunications infrastructure does itself lead to growth because its products - cable, switches, etc. - lead to increases in the demand for the goods and 
services used in their production. In addition, the economic returns to telecommunications infrastructure investment are much greater than the returns just on the telecommunication investment itself. The transactions costs of ordering, gathering and processing information, searching for services are high. As the telephone system improves, the costs of doing business fall, and output will increase for individual firms in private sectors contribution of economic growth. "If the telephone does have an impact on a nation's economy, it will be through the improvement of the capabilities of managers to communicate with each other rapidly over increased distances" [Hardy (1980), p. 279].

Since 1993, Sudan has witnessed an increase in telecommunication infrastructure capacity and developments in information technology to benefit from ICT contribution. Considering the significant expansion of the Sudanese ICT infrastructure in recent years, a lack of empirical studies exists concerning its impact and causal relationship with economic growth. However, two questions arise. Does ICT development lead to economic growth in Sudan? Is there long run and short run relationship between ICT development and economic growth in Sudan economic?

This study is attempted to investigate how ICT development affects economic growth in Sudan. This issue is important and has received considerable attention in the popular press concerning the creation of the "information superhighway" and its potential impacts on the economy. This investigation provides empirical evidence on the major theoretical debates regarding the linkages between ICT development and economic growth. Although many researchers have provided empirical evidences for the correlation between ICT investment and economic growth, study on the impact of ICT development on economic growth is still an unexplored area. Therefore, this paper would fill the literature gap on the effect of ICT development on economic growth.

The rest of this paper is organized in the following way: The next section is a review of relevant studies on the impact ICT on Economic growth. Section three provides Overview of ICT and stylized facts in Sudan. Section four presents the data and econometric methodology used in this study. Section five shows the empirical results and discussion. The last section provides some concluding remarks and discusses policy implications of findings and recommendations.

\section{LITERATURE REVIEW}

Several empirical studies have shown that the benefits of ICT have powered the productivity and economic performance of developed nations over the last four decades. Most studies in developed and industrialized countries report that ICT plays a key role in economic performance during the 90s, such as Lau and Tokutsu (1992) examined the relationship between ICT and economic growth in US over the period 1960-1990 using the production function approach. The findings found that ICT had contributed to nearly half of the national output during the period. Kraemer and Dedrik, (1993), investigated the impact of ICT to economic growth in eleven Pacific countries for the period 1983 to 1990. The results indicating that there was a significant and positive relationship between ICT and economic growth. Niininen (1998) estimated the contribution of ICT to Finland's economic growth for the period 1983 to 1996 using the growth accounting framework. Other empirical researches showed the same results for US include Oliner ans Sichel, (2000); Jorgenson and Stiroh (2000).. Niininen (2001) and Jalava and Pohjola $(2005,2007)$ in the context of Finland; Oulton (2002) in the context of the U.K examined the contribution of ICT to economic growth over the period 19891998; Gretton et al. (2002) and Simon and Wardrop (2002) in the context of Australia; Kegels et al. (2002) in the context of Belgium; Miyagawa et al. (2002) in the context of Japan; 
Armstrong et al. (2002) and Khan and Santos (2002) in the context of Canada; Cette et al. (2002) in the context of France; Van der Wiel (2002) in the context of the Netherlands; and Kim (2002) in the context of South Korea.

Many of these early studies focused on labor productivity, which made the findings surprising as investment in ICT adds to the productive capital stock and should thus, in principle, contribute to labor productivity growth. Later studies found some evidence of a positive impact of ICT on labor productivity, however, some also found evidence that ICT capital had larger impacts on labor productivity than other types of capital, suggesting that there might be spillovers from ICT investment or that ICT might have positive impacts on economic growth. More recent work for certain OECD countries, e.g. the United States and Australia, has more conclusively also found significant interactions between ICT use and complementary organizational variables in nearly all sectors. The complementary factors for which data were available and which were found to have significant influence were: human capital, a firm's experience in innovation, its use of advanced business practices and the intensity of organizational restructuring. Computer use was also commonly associated with use of advanced business practices, the incorporation of companies and firm reorganization by (Gretton, et al., 2004; Bosworth and Triplett, 2003). On the other hand, comparative studies between developed and developing countries indicate that, in contrast to developed countries, developing countries do not experience significant returns from ICT development (see Dewan \& Kraemer 2000). In the Middle East, Nour (2002) uses data from Egypt and other Arab Gulf countries and reports that the correlation between ICT development and economic growth is positive, but not significant. A large-scale study that examines the causality for 105 countries (Shiu \& Lam 2008a) reveals bi-directional causality in high income level and European countries, but uni-directional causality in countries with lower income levels that runs from economic growth to ICT development. They suggest that less-developed countries should create the environmental conditions called 'critical mass' by promoting greater ICT penetration rates. In another study, Lam and Shiu (2010) confirm their previous results by assessing the impact of mobile telecommunications on economic growth.

Hardy (1980) is one of the first studies we are aware of that investigates the potential impact of telecommunication on growth. Using data for over 15 developed and 45 developing nations from 1960 to 1973, Hardy concludes that telephones per capita do have a significant impact on GDP, whereas the spread of radio does not. However, when the regression is attempted for developed and developing economies separately, no significant effects occur. One explanation of this might be that there are important fixed effects. Neither fixed effects nor the problem of reverse causality was addressed by Hardy.

Study by Greenstein and Spiller (1995) who investigate the impact of telecommunication infrastructure (as measured by the amount of fiber-optic cable employed) on economic growth in the U.S. They find that a positive and significant effect exists (output increases some 10\% from doubling the amount of fiber-optic cable) in one industry, whereas in manufacturing sectors less of a telecommunications growth effect exists.

Röller and Waverman (1996) use evidence from 21 OECD countries over the past twenty years to examine the impacts that telecommunications developments may have had. The empirical results show the evidence of a positive causal link, provided that a critical mass of telecommunication infrastructure is present.

Piatkowski (2003) investigated the impact of ICT on economic growth in Poland over the period 1995-2000 using growth accounting framework. The results found that the increase ICT investment had contributed nearly $9 \%$ of Poland economic growth during the sample period. 
A similar study Quesada \& Mas (2005) showed that ICT investment has enhanced economic performance of Spain from 1985-2002 and Daveri (2000) study in 11 OECD countries found that ICT contributed significant to economic growth of most OECD countries.

Colecchia and Schreyer (2002), estimated contribution of ICT on output growth in nine OECD countries over the period of 1980-2000. The empirical results showed ICT contributed between $20 \%$ and $50 \%$ of the national output growth over the study period in most countries. Mudiarasan \& Shanmugam (2007) the study used auto-regressive distributed lag (ARDL) to investigate the relationship between ICT and real gross domestic product (RGDP) for Malaysian economy over the period 1960-2004. The causality results showed that for period 1960-1982, economic growth led to growth in ICT investment, in the second period 19832004, reverse causality was observed ICT investment led economic growth in Malaysia.

\section{Overview of ICT and stylized facts in Sudan}

Sudan's primary resources are agricultural, but oil production and export are taking on greater importance since October 2000 till the secession of south part of the country 2011. The Sudanese economy has grown quite rapidly over the last 10 years with total GDP at current market prices increasing from just over US\$15 billion in 2002 to almost $\$ 67.32$ billion in 2011. Real GDP growth has been especially strong in 2006 and 2007 registering 8.9 percent and 8.5 percent, respectively, largely as a result of increased oil production, higher oil prices and expanded export processing zones, then decreased gradually and became 2 percent in 2012 due the secession of South Sudan which resulted in an $80 \%$ decline in foreign currency earnings and a 35.6\% reduction in budget revenue. Real GDP grew by $2.8 \%$ in 2011, down from $5 \%$ in 2010. This slowdown in growth is attributable to the loss of oil revenues, and GDP growth is estimated to decline further to $2 \%$ in 2012.

Sudan's experience of the last two decades in building and capitalizing on ICT as a gateway for sustainable development is a landmark in the country's history. The institutional, legal, and regulatory frameworks were reformed to advance ICT as tools for integrating the economy into the global market. However, the full potential ICT is greatly hampered by the lack of capacity of communities to make the best use of the services. Therefore, UNDP is intervening to assist the government through its ICT institutions to promote ICT for human development.

Communications and facilities are still limited outside Khartoum while travel restrictions are also in force in some areas (for example Darfur region) owing to political instability. This has had a negative impacted upon recent attempts to stimulate growth in the country's ICT sector. Nevertheless, there has been steady growth in the usage of telecommunications and internet during the past years.

The historical use of ICT in Sudan, according to the WDI database (2005) implies that before 2000 the number of users both mobile-cellular telephones and internet (per1000 population) were zero and up till the year 2000 both were only one. In recent year Sudan has shown growing telecommunication networks and internet services but still the highest price/most expensive internet service compared to other Africa and developing countries.

Below are the present recent indicators from international telecommunication Union ITU (2014) and illustrate that despite recent shown in terms of fixed telephone, the present average growth rate of the total online population. Internet, fixed (wired) broadband and mobile -cellular subscribers in Sudan during the period 2000-2013 has been significant. 
The status and trend of ICT indicators in Sudan the fixed-telephone subscriptions per 100 inhabitants increased from 1.13 in 2000 to 1.48 in 2005 but then declined to 1.25 and to 1.09 in 2010 and 2013 respectively. In addition mobile-cellular telephone subscriptions per 100 inhabitants increased from 0.07 in 2000 to 4074, 41.54 and to 72.85 in 2005, 2010 and 2013 respectively. Moreover fixed (wired)-broadband subscriptions per 100 inhabitants increased from 0.002 in 2004 to $0.003,0.03$ and 0.12 in 2005, 2010 and 2013. Furthermore the percentage of individuals using the internet increased from 0.03 in 2000 to $1.29,16.70$ and 22.70 in 2005,2010 and 2013 respectively.

The rapid increase in ICT indicators in Sudan that appear from the increasing use of internet and mobile-cellular telephone in Sudan over the period 2000-2013, are above that of African region but below Arab region, whereas the use of fixed-telephone in Sudan less than Africa and Arab region. This implies that by regional and international standard the ICT indicators in Sudan are below. Comparing Sudan ICT performance with other countries we find, mobilecellular telephone subscriptions per 100 in Sudan 72.85 in 2013 ranked in sixth bottom place in the Arab countries after (Djibouti, Comoros, Somalia, Syria, and Yemen). The top performance in the Arab region that reported in Kuwait 190.29 is equivalent to 2.61 times that in Sudan. Fixed-telephone subscriptions per 100 inhabitants in Sudan 1.09 ranked in the second bottom place in Arab countries after Somalia, the top performance in the Arab region reported in United Arab Emirates 22.32 is equivalent to 20.48 times that of Sudan.

\section{DATA AND METHODOLOGY}

The study uses ICT variables data covering the period from 1980-2014 extracted from the International Telecommunication Union (ITU), such as (fixed telephone line and mobile cellular telephone (FIXMOB) and internet (INT) subscribers per 100 inhabitants) used as a proxy for ICT infrastructure. Since economic growth is strongly affected by the macro economic conditions, some economic factors which may influence the connection between ICT development and economic growth are traditional factors of production included in this study. Gross fixed capital formation (GFCF) data that is calculated in US dollars, constant prices 2005 and total civilian labor force as proxy of human capital have been considered of the main factors of economic growth both in developed and developing countries.

To investigate the relationship between ICT and economic growth, most extant empirical studies at the macro level utilize the production function with ICT as an explanatory variable. This study makes use of the framework proposed by Solow (1957) and Jorgenson (1966), and also used by Haghshenas \& Berma, 2013; consider the aggregate production function in the form of the production possibility frontier. The basic production function is extended to take into account the technological progress, embodied in the form of ICT capital and non-ICT capital. Therefore, the typical production function for examining the impact of ICT on output requires three resources: labor, ICT capital and other capitals. If production is assumed to follow a Cobb-Douglas function form, the following production function is utilized:

$$
Y=A I C T^{\alpha} K^{\beta} L^{\gamma}
$$

Where Y is Growth Domestic Product (GDP), ICT information communication and technology represents special form of capital to estimate its impact on growth, $\mathrm{K}$ denotes other capitals and $\mathrm{L}$ denotes labor force. $\mathrm{A}$ is constant representing other factors of production, and $\alpha, \beta$ and $\gamma$ are the elasticities of production resources. The function can be converted into the following log-linear form for analytical convenience:

$$
\ln Y=\ln A+\alpha \ln I C T+\beta \ln K+\gamma \ln L
$$


Based on this theory, first standard test based on the work of Dickey and Fuller (1979) is performed. Moreover, Cointegration techniques such as Johansen (1988), Johansen-Juselius (1990) and Pesaran and Pesaran (2001), ARDL approach are utilized in the economic literature to empirically determine the existence of any long-run relationship among the variables. The ARDL model has some advantages over other cointegration approaches. The appropriateness of utilizing ARDL model is that the ARDL model is based on a single equation framework. The ARDL model takes sufficient numbers of lags and direct the data generating process in a general to specific modeling framework (Harvey, 1981). Unlike further multivariate cointegration techniques such as Johansen and Juselius (1988), ARDL model permits the cointegration relationship to be estimated by OLS once the lag order of the model is identified. Error Correction Model (ECM) can also be drawn from by ARDL approach (Sezgin and Yildirim, 2003). The above advantages of the ARDL technique over other standard cointegration techniques justify the application of ARDL approach in the present study to analyze the relationship among variables. The short and long-run parameters are estimated simultaneously. The unrestricted error correction model is used for equation- 1 as following:

$$
\begin{aligned}
\Delta \ln G D P=\beta_{0} & +\alpha_{1} \ln G D P_{t-1}+\alpha_{2} \operatorname{lnGFCF}_{t-1}+\alpha_{3} \ln I C T_{t-1}+\alpha_{4} \ln L F_{t-1}+\sum_{i=0}^{n} \beta_{1 i} \Delta \ln G D P_{t-1} \\
& +\sum_{i=0}^{n} \beta_{2 i} \Delta \ln G F C F_{t-1}+\sum_{i=0}^{n} \beta_{3 i} \Delta \ln I C T_{t-1}+\sum_{i=0}^{n} \beta_{4 i} \Delta \ln L F_{t-1}+e_{t}
\end{aligned}
$$

For short run behavior of the variables, we use error correction version of ARDL model as following:

$$
\begin{aligned}
\Delta \ln G D P=\beta_{0} & +\sum_{\substack{i=0 \\
n}}^{n} \beta_{1 i} \Delta \ln G D P_{t-1}+\sum_{i=0}^{n} \beta_{2 i} \Delta \ln G F C F_{t-1}+\sum_{i=0}^{n} \beta_{3 i} \Delta \operatorname{lnICT_{t-1}}+\sum_{i=0}^{n} \beta_{4 i} \Delta \ln L F_{t-1} \\
& +\lambda E C M_{t-1}+u_{t}
\end{aligned}
$$

Where $\lambda$ is the speed of adjustment parameter and EC is the residuals that are obtained from the estimated cointegration model. The stability tests such as cumulative sum of recursive residuals (CUSUM) and cumulative sum of squares of recursive residuals (CUSUMSQ) are also applied to test the goodness of fit for ARDL model.

\section{EMPIRICAL RESULTS AND DISCUSSIONS}

In this section, empirical results are presented along with their analysis by using ARDL approach. Before applying ARDL, the Augmented Dickey-Fuller (ADF) test was employed to test the stationary of time-series data considered under the study and the results are presented in Table (1), ICT indicators are stationary at I(0) and the other variables are integrated at I(1) and we should apply ARDL bounds testing approach to co integration to test long run relationship between the variables.

TABLE (1) Tests of the Unit Root Hypothesis

\begin{tabular}{lll}
\hline & Aug Dickey-Fuller test & \\
\hline Variable & Level & First differences \\
\hline GDP & -2.26561 & $-4.414967^{* * *} \mathrm{I}(\mathrm{I})$ \\
FIXMOB & $-4.339838^{* * *} \mathrm{I}(0)$ & -0.52452123 \\
Internet & $29.69303^{* * *} \mathrm{I}(0)$ & -5.841027 \\
GFCF & -1.1249191 & $-4.563698^{* * *} \mathrm{I}(1)$ \\
LF & -1.259318 & $-6.276242^{* * *} \mathrm{I}(1)$ \\
\hline
\end{tabular}


Note: The optimal lag is automatically selected based on the Schwarz Info Criterion (SIC) for

Fisher-ADF regressions. ${ }^{* * *}$ and ${ }^{* *}$ denote the rejection of the null hypothesis of non-stationary at the $1 \%$ and $5 \%$ levels of significance, respectively.

\section{SOURCE: Author}

To examine the long run relationships between information and communication technology ICT and economic growth in Sudan, this study uses recent co-integration analysis approach, known as autoregressive-distributed lag (ARDL) model \{Pesaran et al(2001)\}, All other techniques require the same level of Stationary of variables for further process

Table (2): ARDL bound test result

\begin{tabular}{ccc}
\hline F-Statistics & \multicolumn{2}{c}{6.594048} \\
\hline Significance & Critical value bounds \\
$10 \%$ & 10 bounds (lower bounds) & 11 bounds (upper bounds) \\
$5 \%$ & 2.45 & 3.52 \\
$2.5 \%$ & 2.86 & 4.01 \\
$1 \%$ & 3.25 & 4.49 \\
\end{tabular}

SOURCE: Author

But the ARDL model provides and substitute test for examining a long run relationship regardless of whether the underlying variables are I(0), I(1), or fractionally integrated.. Table (2) demonstrating results of F-Statistics value comes more than critical value of bounds. It indicates long run relationship among the variables.

Table 3: Error correction representation for ARDL model Dependent variable is DLOG(GDP)Preferred specification

\begin{tabular}{|c|c|c|c|c|}
\hline \multicolumn{5}{|c|}{ Cointegrating Form } \\
\hline Variable & Coefficient & Std. Error & t-Statistic & Prob. \\
\hline DLOG(FIXMOB) & 0.130906 & 0.071318 & 1.835523 & 0.0406 \\
\hline $\mathrm{D}(\mathrm{INT})$ & -0.010716 & 0.010102 & -1.060824 & 0.3008 \\
\hline DLOG(LF) & -0.363828 & 0.206585 & -1.761154 & 0.0928 \\
\hline DLOG(LF(-1)) & 0.236070 & 0.232401 & 1.015785 & 0.3213 \\
\hline $\operatorname{DLOG}(\operatorname{LF}(-2))$ & -0.501082 & 0.250220 & -2.002568 & 0.0583 \\
\hline $\operatorname{DLOG}(\operatorname{LF}(-3))$ & -0.384589 & 0.221959 & -1.732700 & 0.0978 \\
\hline DLOG(GFCF) & 0.301576 & 0.115945 & 2.601030 & 0.0167 \\
\hline DLOG(GFCF $(-1))$ & -0.002961 & 0.120133 & -0.024650 & 0.9806 \\
\hline DLOG(GFCF $(-2))$ & -0.124910 & 0.111345 & -1.121828 & 0.2746 \\
\hline DLOG(GFCF $(-3))$ & -0.311284 & 0.116822 & -2.664597 & 0.0145 \\
\hline CointEq $(-1)$ & -0.651847 & 0.144215 & -4.519963 & 0.0002 \\
\hline \multicolumn{5}{|c|}{ Long Run Coefficients } \\
\hline Variable & Coefficient & Std. Error & t-Statistic & Prob. \\
\hline LOG(FIXMOB) & 0.200823 & 0.110087 & 1.824222 & 0.0424 \\
\hline INT & -0.016440 & 0.016432 & -1.000466 & 0.3285 \\
\hline LOG(LF) & 0.388623 & 0.214288 & 1.813556 & 0.0541 \\
\hline LOG(GFCF) & 1.318317 & 0.214791 & 6.137660 & 0.0000 \\
\hline $\mathrm{C}$ & -6.129929 & 5.167518 & -1.186242 & 0.2488 \\
\hline \multicolumn{5}{|c|}{ Diagnostic tests } \\
\hline \multicolumn{5}{|c|}{0.821} \\
\hline D.W & \multicolumn{4}{|l|}{2.14} \\
\hline \multicolumn{5}{|l|}{ Breusch-Godfrey LM } \\
\hline$\chi 2(1)$ & \multicolumn{4}{|l|}{$3.71(0.155)$} \\
\hline
\end{tabular}

\section{SOURCE: Author}

The result of the long - run relationship between fixed and mobile telephone, labour force and GFCF in table (3) reveal that the estimated coefficients has a positive and significant impact on economic growth, one percent increase in (fixmob) to contribute 0.20 percent of GDP. On the other hand the intent (INT) coefficient is found to be statistically insignificant and has 
unexpected negative sign. However, econometric analysis brings evidence that the effect of the macroeconomic variables (gross fixed capital formation and labour force) on the economic growth in Sudan is more important than that of ICT indicators effect.

The short run effect of FIXMOB is significant at 5 per cent level, similar to the long run case but the magnitude of the effect is slightly lower than the long run case. Moreover, the results indicate the error correction coefficient estimated at $(-0.6518)$ has negative sign and statistically significant, getting adjusted of $65.18 \%$ convergence towards equilibrium at the long run. This also indicates once the disequilibria happened, it will take more than one year to adjust itself towards the long run equilibrium. Moreover, the last part of Table 3 describes a bundle of diagnostic tests to understand the validity of the result of error correction model. The adjusted R square shows around 82 per cent of the variation of data is explained by the model. The Durbin-Watson (DW) statistic (2.14) is close to 2, which roughly indicates that the model is free of autocorrelation problem. The Breusch-Godfrey LM test for serial correlation is more appropriate for dynamic models and we see, this model passes this test.

The stability tests done on the ARDL model, using plots of "Cumulative Sum of Recursive Residuals (CUSUM)" and "Cumulative Sum of Squares Recursive Residuals (CUSUMSQ)" presented by Brown et. at (1975) has been shown in figure (1) and figure (2) respectively. Since both the plots remain within critical bounds at 5 percent level of significance. We conclude that the model is structurally stable.

Figure (1): Plot of cumulative Sum of Recursive Residuals

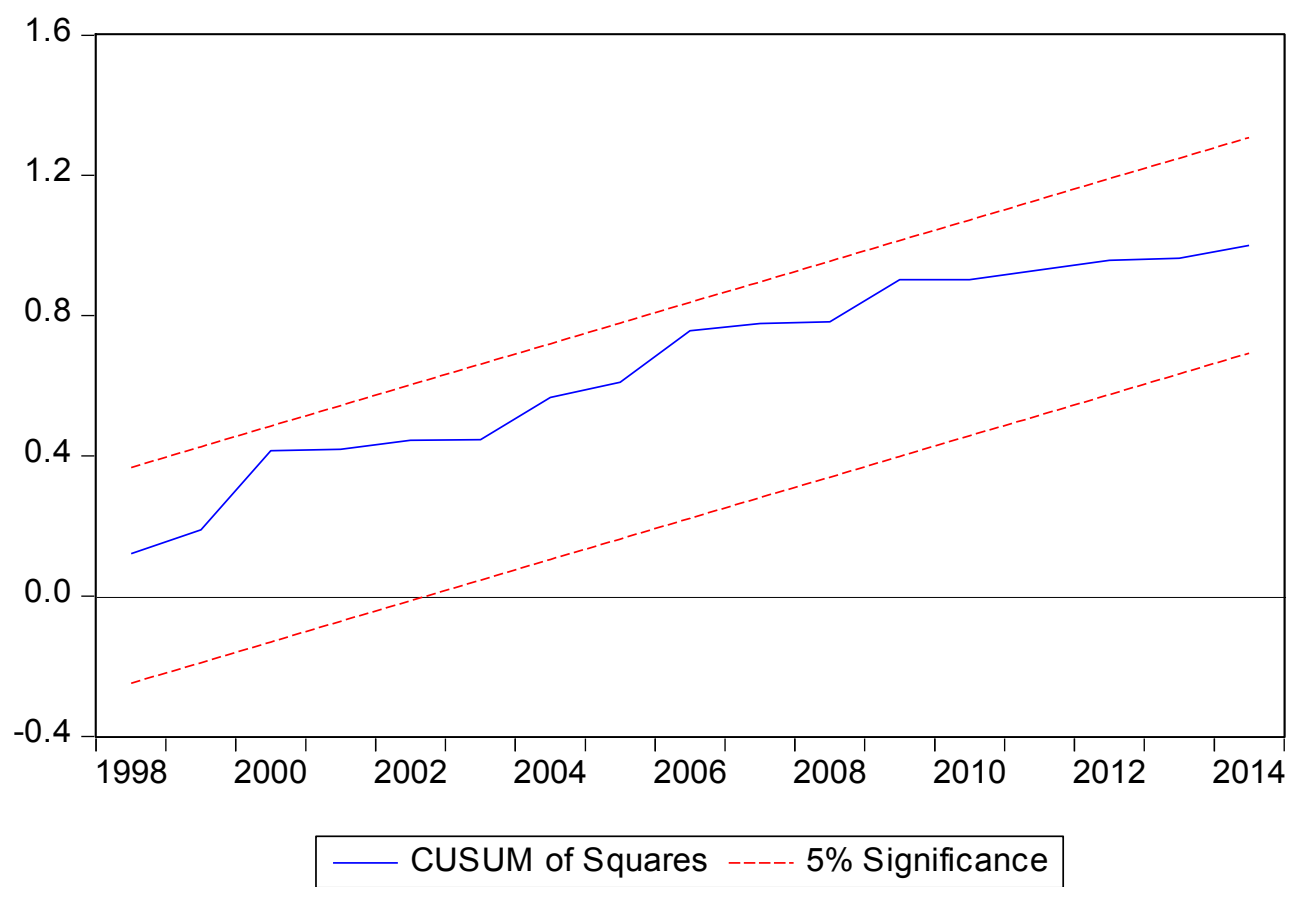




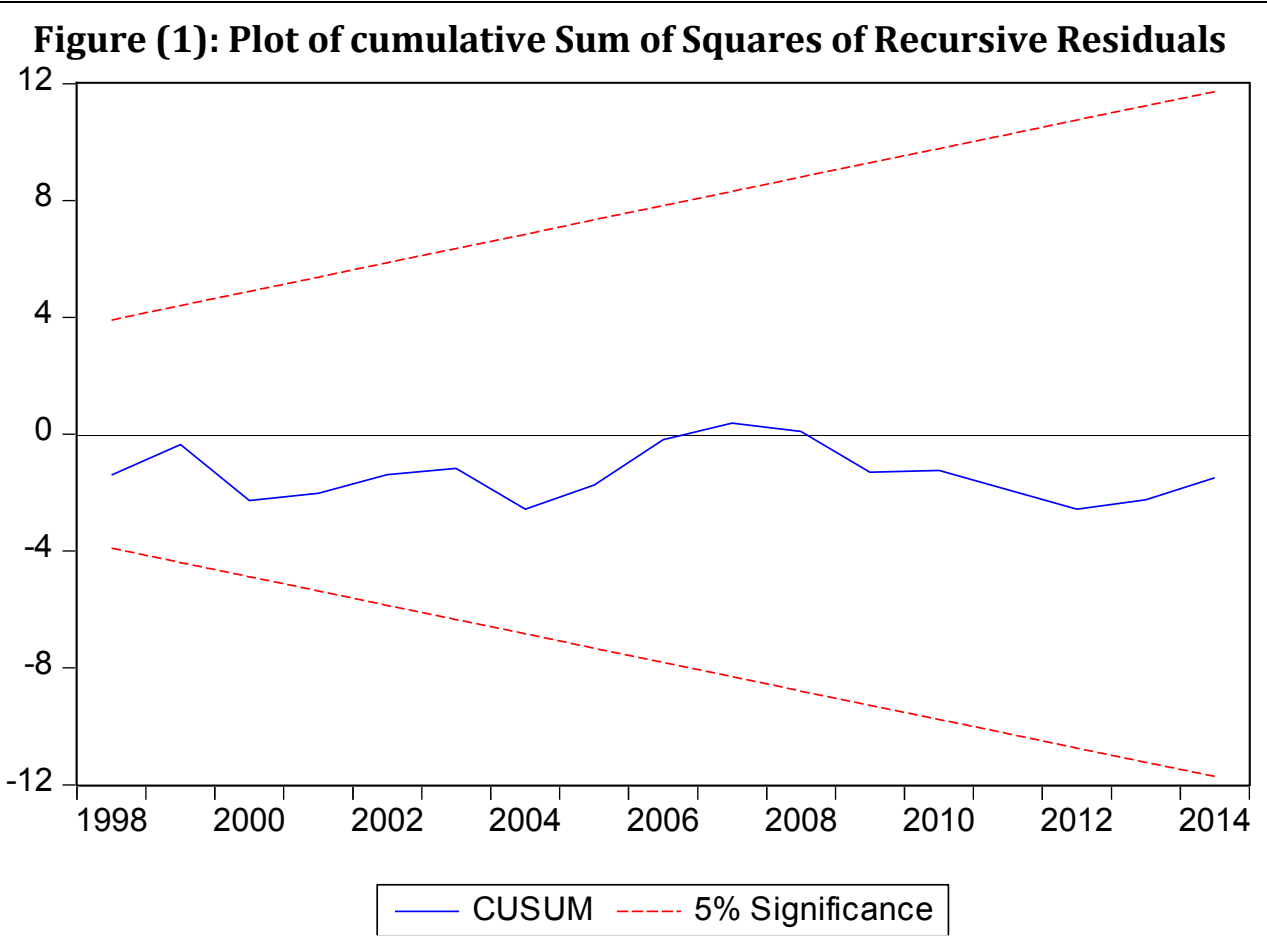

The fact that must studies have shown, positive relationship between ICT and economic growth, the results corroborate with existing empirical works (Kraemer and Dedrik, (1993), Piatkowski (2003), Greenstein and Spiller (1995), Shiu \& Lam 2008).

\section{CONCLUDING REMARKS AND RECOMMENDATIONS}

This study employed the Augmented Cobb-Douglas production function to investigate the relationship between information \& communications technology and economic performance. The results showed that ICT development has a significant effect on the economic growth in Sudan. The coefficient measuring the effect of the fixed telephone and mobile cellular development on economic growth was positive, indicating that ICT affect economic growth in a positive way both long-run and short-run. The findings are consistent with existing theoretical framework as illustrated by several authors about the relationship between ICT development and economic growth. Therefore it is essential for the government to provide the society with information, up-to-date structures and educated people in other to access and use ICT efficiently.

Moreover, the study may have implications for policy makers who should focus mainly on ICT indicators because Sudan economy is still under the transition period and needs more efforts to develop ICT components by implementing specific policies that will accelerate ICT development.

\section{Reference}

Armstrong, P., Harchaoui, T., Jackson, C. \& Tarkhani, F. 2002. A Comparison of Canada-U.S. Economic Growth in the Information Age, 1981-2000: The Importance of Investment in Information and Communication Technologies.

Canada: Statistics Canada, Analytical Studies Branch.

BOSWORTH, B.P and J.E. TRIPLETT (2003), “Services Productivity in the United States: Griliches' Services Volume Revisited”, paper prepared for CRIW Conference in Memory of Zvi Griliches, Brookings Institution, Washington, DC, September.

Colecchia and Schreyer (2002), "ICT investment and economic growth in 1990s: is the US a unique case?" A comparative study of nine OECD countries", review of economic dynamics, 5: 408-442.

Cette, G., Kokoglu, Y. \& Mairesse, J. 2000. The diffusion of Information and communication technologies in France: Measurement and contribution to growth and productivity. Economie and Statistique 339(40): 73-91. 
Arabi, A. M. K., \& Allah, B. A. W. (2017). The Impact of Information and Communication Technology (ICT) Development on Economic Growth in Sudan: An Application of ARDL Bounds Testing Approach. Archives of Business Research, 5(3), 155-165

Daveri, F. (2000), "Is growth of information technology story in Europe too?” university of Prma and IGIER. mimo

Dewan, S. \& Kraemer, K. L. 2000. Information technology and productivity: preliminary evidence from countrylevel data. Management Science 46(4): 548-562.

GRETTON, P., J. GALI and D. PARHAM (2004), “The Effects of ICTs and Complementary Innovations on Australian Productivity Growth", in OECD (2004), the Economic Impact of ICT - Measurement, Evidence and Implications, OECD, Paris.

Hardy, A., 1980, "The Role of the Telephone in Economic Development," Telecommunications Policy, 4: 278-286.

Jalava, J. \& Pohjola, M. 2005. ICT as a source of output and productivity growth in Finland. Helsinki Center of Economic Research, Discussion Paper 52: 1-11.

Jalava, J. \& Pohjola, M. 2007. ICT as a source of output and productivity growth in Finland. Telecommunications Policy 31(8): 463-472.

Jorgenson, D.W \& Stiroh, K.J, (2000), "Raising the speed limit: US economic growth in the information age", Brooking papers on economic activity1: 125-211.

Kegels, C., Van Overbeke, M. \& Van Zandweghe, W. 2002. ICT Contribution to Economic Performance in Belgium: Preliminary Evidence. Federal Planning Bureau, Working Paper, 8(02).

Khan, H. \& Santos, M. 2002. Contribution of ICT Use to Output and labour Productivity Growth in Canada. Bank of Canada Working Paper, 7.

Kim, S. J. (2002). The Digital Economy and the Role of Government: Information Technology and Economic Performance in Korea. Program on Information Resources Policy, Harvard University.

Kraemer, K. and Dedrik, J. (1993) "Payoffs from investment in ICT. Lesson from the Asia-Pacific Region”, CRICTO National ICT policy publications.

Leff, Nathaniel H., 1984, "Externalities, Information Costs, and Social Benefit-Cost Analysis for Economic Development: An Example from Telecommunications," Economic Development and Cultural Change, 32: $255-276$.

Lam, P-L., \& Shiu, A. 2010. Economic growth, telecommunications development and productivity growth of the telecommunications sector: evidence around the world. Telecommunications Policy 34(4): 185-199

Mudiarasan \& Shanmugam (2007), Islamic Countries Economic Growth and ICT Development: the case of Malaysian Case, journal of economic cooperation, 28,1 (2007), 99-114

Niininen, P. (1998), “computers and economic growth in Finland”. Working paper: 148, UNU/WIDER.

Niininen, P. 2001. Computers and economic growth in Finland. In Information Technology, Productivity, and Economic Growth: International Evidence and Implications for Economic Development, edited by Pohjola, M., 175-195. Oxford: Oxford University Press.

Nour, S. 2002. The Impact of ICT on Economic Development in the Arab World: A comparative study of Egypt and the Gulf countries. Ninth Annual Conference of the Economic Research Forum (ERF). Sharjah.

Lau, L.J. \& Tukutsu, I. (1992), "the impact of computer technology on the aggregate productivity of the United States: An indirect approach", working paper Stanford CA: department of economics. Stanford University mimeo.

Oliner, S, \& Sichel, D. (2000), Resurgence of growth in the late 1990s: Is Information Technology the Story?, Finance and Economics Discussion Series 2002-20, the Federal Reserve Board US>

Oulton, N. 2002. ICT and productivity growth in the UK. Oxford Review of Economic Policy 18(3): 363-379

Piatkowski (2003), "the contribution of ICT investment to economic growth and labor productivity in Poland 1995-2000"TIGER working paper series No. 43, July 2003.

Quesada, J. \& Mas, M. (2005), "ICT and economic growth: A Quantification of productivity growth in Spain 19852002", OECD statistics working paper, STD/DOC 2005(4): 1-56

Röller and Waverman (1996), Telecommunications Infrastructure and Economic Development: A Simultaneous Approach, Discussion Paper FS IV 96 - 16, Wissenschaftszentrum Berlin

Simon, J. \& Wardrop, S. 2002. Australian Use of Information Technology and its Contribution to Growth. Research Discussion paper, 02, Economic Research Department, Reserve Bank of Australia. 
Shiu, A. \& Lam, P. L. 2008a. Causal relationship between telecommunications and economic growth: a study of 105 countries. Paper presented at the 17th Biennial Conference of the International Telecommunications Society. Montreal.

SOLOW, R.M. (1987), “We’d Better Watch Out”, New York Times, July 12, Book Review, No. 36 